\title{
Any Material Way
}

\section{NATHAN K. HENSLEY}

$\mathrm{I}_{\mathrm{T}}^{\mathrm{T}}$ $T$ is an honor to have the chance to discuss publicly Elaine Freedgood's work and its effects_- "incalculably diffusive," as they say in Middlemarch-in the world. ${ }^{1}$ George Eliot is an idealist and Elaine a materialist, which means that tracing Elaine's work and its work in the world, unlike that of the more pious and boring Dorothea Brooke, is possible. You can touch it. To do this labor of tracing will require thinking about Elaine's commitment to the category of the material, against the ideal and the idealized; it will also require thinking about the place that the conceptual or theoretical, but also the affective and communal, occupy for her, in relation to what Raymond Williams used to call concrete social processes. ${ }^{2}$ If Dorothea has a "finely tuned spirit," with "many fine issues," Elaine's allegiances push her away from finery, away too from "spirit." Away, as she says in her reading of this very passage, from "mysterious, quietist, and . . . deeply sentimental form [s]" of consolation and toward "larger historical processes that cannot be domesticated."3

For all its conceptual ambition and plainspoken bravado, Elaine's intellectual practice is concerned ultimately with vulnerable things: the predicaments of bodies in space. Bodies arranged in power relations, inhabiting physical situations. This commitment to the concrete conditions of actual people and things_call it the historical-I admire with my entire self. At our event in September I tried to honor it with a prop.

It's just a cup (fig. 1). Beautiful, in its way-though cracked, like Henry James's bowl. It is thin-lipped, which I like in a sipping cup, and gilt-edged. It says "Wedgwood" on the bottom, "Etruria, England" (fig. 2). As antiquarians know, these marks indicate by code the origin, maker, andafter deciphering - the date of the piece. This ghostly language tells us that the cup I passed on to Elaine was made between 1891 and 1900, in Etruria, one of the six towns now comprising Stoke-on-Trent, epicenter of the Staffordshire trade and the site of Wedgwood's most important factory.

The whiteness of the cup, its translucency, and the fact that it won't break when you pour hot liquid into it all follow from its composition:

\footnotetext{
Nathan K. Hensley is an associate professor of English at Georgetown University. He is the author of Forms of Empire: The Poetics of Victorian Sovereignty and coeditor, with Philip Steer, of Ecological Form: System and Aesthetics in the Age of Empire. His current project is about failing systems.
} 


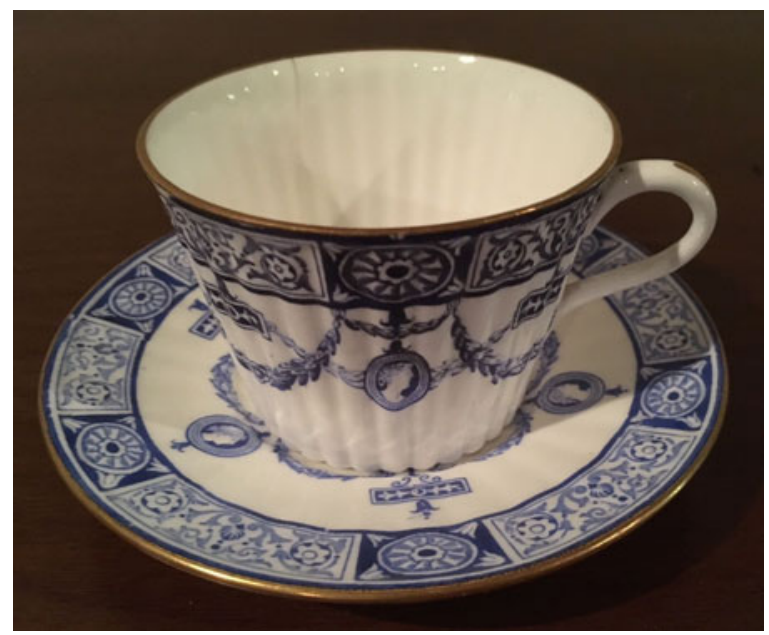

Figure 1. Wedgwood cup and saucer presented to Elaine Freedgood, September 21, 2018. Bone china, pattern “Adams Blue," ca. 1890s.

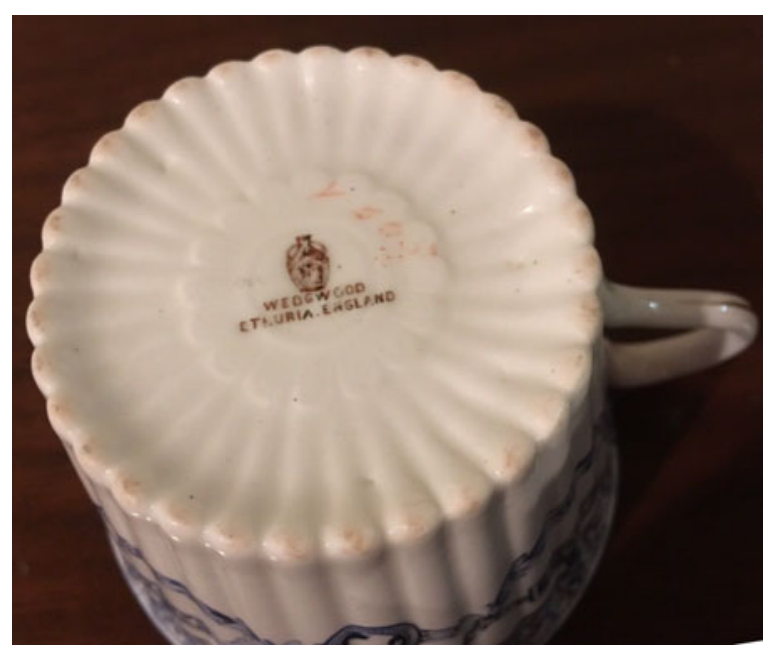

Figure 2. Wedgwood cup, markings showing provenance between 1891 and 1900.

between 48 and 50 percent of it is bone ash, made from the incinerated bones of domestic animals. Cattle, in this case, their skeletons heated in coal furnaces to a temperature of $1,832^{\circ} \mathrm{F}$, until calcification transpired and the biotic remains of those anonymous and forgotten beings became powder. I'll get to the thing shortly. First some ideas in it.

When the occasion for this symposium was announced to me, I'd been thinking already about commitment - the question of worldliness- 
in art and thought. But it was impossible to read anything on that topic without being reminded of Elaine, whose life as a human being and as a scholar has been driven by an effort, across those spheres, to "resist the course of the world," in the words of Adorno's essay on "Commitment," by recognizing, and lifting up, those who feel its pistol most coldly against their skin. ${ }^{4}$ One thing Elaine's work does is blow apart the false problem Adorno stages in his essay, which presumes that formally attuned and engaged criticism are natural enemies. Can you study poetic tropes like metonymy or analepsis, and undertake that essentially formalist analysis, but do so precisely in order to chart the regimes of extraction and violence on which everyday bourgeois comfort-the curtains in Mary Barton, the snacks at our September eventhas been, and is still, predicated? Can you care about free indirect discourse, or the function of denotative effects like lists, but care, too, about the stakes of these highly mediated devices for the lived experience of precarious and exploited human beings, in the past and now? And more: can this commitment at the level of method and scholarly practice be lived out, also, in the conduct of life? In the way you actually act in the actual world?

Elaine's example lets us say yes. The continuity of this commitment would shame Adorno, who called for the abolition of bourgeois life but listened to music while his students barricaded streets in May 1968. It touched me at a dumpling restaurant in midtown Manhattan, when, just two years ago, I first met Elaine in person. Up to that point I'd known her only in print, as a Famous Victorianist I Admired. She didn't know me either, except through a few items of correspondence I enjoyed reviewing recently ("Dear Elaine, if I may ...."). I was starstruck, sweating. Untenured. At some point during our lunch she handed me a pamphlet. It was a thin, cheaply printed booklet with smoke on the cover, and she said, relaxed: "I thought you might think this was cool." It was a small gesture of intellectual generosity: unhistoric, Eliot would say. It turned out later, because she didn't press it then, that the book was about the Staffordshire potteries, in the English Midlands, during the Industrial Revolution, perhaps the most polluted and immiserated of Victorian modernity's sacrifice zones. I had just finished co-editing an essay collection whose main subject was carbon-intensive forms of Victorian life-a manuscript Elaine had read for the press with great generosity-and so should have known about the Midlands potteries; even more, I should have written about them. But I didn't, and I hadn't. "While generations of collectors have studied the wares of the 
Potteries," the booklet says, "the circumstances of their production have often been overlooked."

For me, the lunchtime scene captures a central truth about Elaine's intellectual persona, since the reversal of overlooking is a grace note connecting different phases in her surreally generative career. We can find clues in her intellectual genealogy. The Risk book thanks her advisers, three leaders in affirming the power of the minoritized: minor literatures (Steven Marcus); minoritized people (Edward Said); and minor knowledges (Gauri Viswanathan). ${ }^{6}$ Channeling these mentors and furthering their work, Elaine's intellectual loyalty has fallen, always, with the uncanonized and deaccessioned; to historical protagonists and artifacts unsmiled upon by institutional prestige, uncomforted by material security. And her labor has been to show how, from even the most frayed and vulnerable edges of our social systems, the energy of ideation flashes out like an electric spark. "Ephemeral texts," as she calls them in Victorian Writing about Risk: texts that circulate "at the margins of culture" but for that very reason ("paradoxically," she writes) say more about the world than even our most habitually fetishized cultural objects. ${ }^{7}$ Forgotten texts, in the case of her astonishing anthology, Factory Production in Nineteenth-Century Britain, which arrays accounts by laboring women and injured workers and Indian dissidents that are nevertheless (she insists casually, in the preface) "central to any conception of modernity." 8 Or major texts, turned minor. The Ideas in Things squares up to a big four of humanist exhibits, Jane Eyre, Mary Barton, Great Expectations, Middlemarch. But these documents of civilization become in Elaine's treatment something else, speech acts fraught or striated with what she calls "knowledge . . stockpiled in ... things," dark insights coded into tiny, almost illegible notations, usually ignored, that nevertheless cipher "grisly specifics of conflicts that a culture can neither regularly acknowledge nor permanently destroy." In this model of haunted speech, the novels' major idiom has been infiltrated and even sometimes co-opted by what, in a collaboration with Cannon Schmitt, she elsewhere called "understudied languages." ${ }^{10}$ Unruly or forgotten tongues, in other words, minor dialects the powerful can't speak, or won't. In that essay, Cannon and Elaine explain that the boring bits of novels, the parts we skip over, have "heretofore given us space to breathe, allowing us to look through or around it rather than at it." Their project, they say, is "to refuse that space." 11 What I take from Elaine's work and hold near me is this ethic or desideratum: refuse to look through or around; do not ignore, avoid, or pretend otherwise. Decline to overlook. 
Defetishization as an ethic and a practice. Polish no urns; speak no bullshit.

I got back from New York after our dumpling lunch and looked at the pamphlet, as you do when you're junior and a genius hands you something. "The many unpleasant facts of life in the Potteries," it read, "have been obscured by the scores of books on the wares produced, but the character of the Potteries was formed by . . . the working life and people [the factories] enclosed."12

Wedgwood was among the first and is today the most famous of the Staffordshire potters, offering "Luxury Craftsmanship to Ravish the Senses," as the firm's website now says. ${ }^{13}$ If we unravish our senses, we learn from the sources that Josiah Wedgwood pioneered the "methodic revolution ... in the technique of pottery" by shifting this early carbonintensive industry toward mass production, such that "the marks of human handiwork became unrecognizable" (fig. 3). ${ }^{14}$ The resulting benefit was something like perfect form:

Dozens of his plates can be piled up without exerting unequal pressure upon one another, so exactly do they correspond in size and shape; their rims, too, have precisely the right contour. The lids of his jugs and teapots fit perfectly; his handles can be really held, his spouts pour. ${ }^{15}$

I have learned, from reading up on china production, that coded within these ideal forms, behind or ghosted inside them, are clays and minerals dug from Midlands deposits; biotic materials salvaged from animal slaughter; chemical glazes that peeled skin from human bodies; all of this fired with coal stripped from seams surrounding Stoke and worked, of course, by people: the jiggers, dippers, grinders, the workers of bellows, the mould-runners. ${ }^{16}$ According to Engels, who cites Wedgwood by name, these last were "children, with scarcely a single exception, . . . lean, pale, feeble, stunted; nearly all suffer from stomach troubles, nausea, want of appetite, and many ... die of consumption." 17 Those lives are all invisible to us now, gone: unless, of course, we can reverse our tendency to overlook, and see that those marginal human beings are in some small but ontologically real sense still here-enciphered, maybe, in a cup like the one I gave Elaine in September.

Eve Sedgwick says that because they rely on tropes of exposure and understand revelation as their analytical endpoint, suspicious or antifetishistic reading practices like the ones I've been describing are arid and, in a way, inhuman. They can't build, Sedgwick says: they offer no "pleasure," propose no "amelioration."18 Where paranoid reading is 


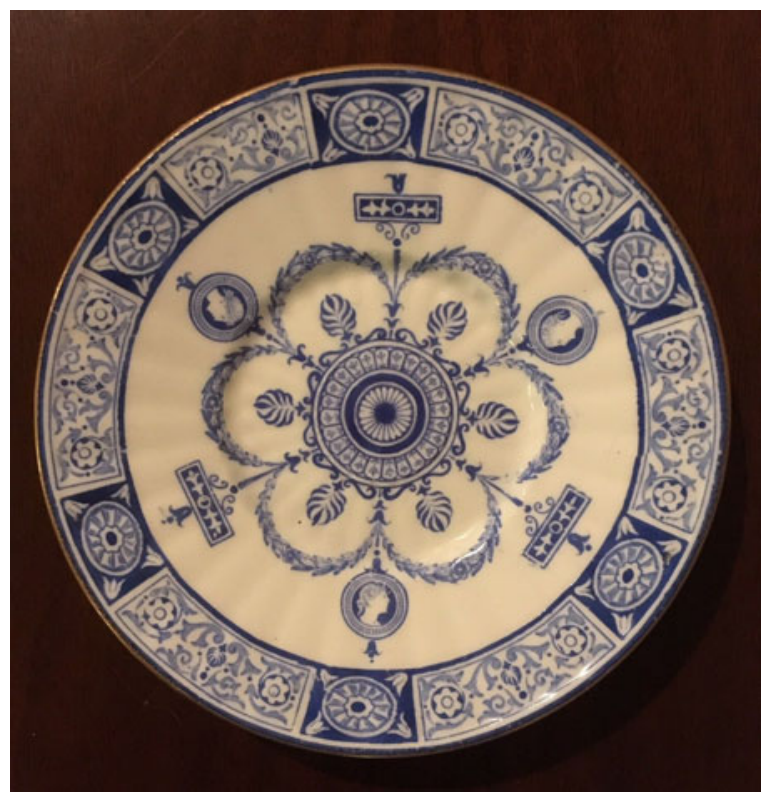

Figure 3. Wedgwood saucer, showing pattern "Adams Blue," ca. 1890s.

negative in orientation, the signal affect of reparative thinking is, Sedgwick says, "love." I have dwelt here on the defetishizing turn of Elaine's work, its power to disenchant and to disclose, the double "dis-" emphasizing what would seem to be the negativity of these modes, their thrall to the unpleasurable, nonameliorating, unbuilding spirit that we are wrongly told travels with critique.

But what form of action is it, paranoid or reparative, critical or loving, to send a junior colleague down the rabbit hole of researching the china trade? To invite him to lunch? To take him seriously enough to have thought of his work in relation to your own, long-ago reading? And then to hand him-physically to pass on to him-a source aimed to supplement and inform that work of his, while (more importantly) opening up for him the lives of the people and nonhuman beings he had previously, in the pamphlet's own words, "overlooked"? What affective disposition is required, I am asking, to give of yourself endlessly, yet to do so not up but down the scale of professional status? To lend a hand to those behind you; to lift them up? ${ }^{19}$ What form of commitment pushes someone to write that same junior colleague a note, months later, that offhandedly mentions her illness - the physical collapse of her own material body-but then gets to its real point, two lines down, with another reference to the concrete? "I think," Elaine wrote me, that "if 
there's any material way in which I should update your letter, I should do that soon." ${ }^{20}$ The love Elaine has shown to me and so many in our field is intellectual in shape, reparative in its essence. It is human; it has built. I hope the cup lasts forever.

\section{Notes}

1. Eliot, Middlemarch, 785.

2. Williams refers to operations of social and cultural mediation as "specific and indissoluble real processes, within which the decisive relationship [between base and superstructure], from a Marxist point of view, is that expressed by the complex idea of 'determination." Williams, Marxism and Literature, 82.

3. Freedgood, The Ideas in Things, 138.

4. "It is not the office of art to spotlight alternatives," writes Adorno, "but to resist by its form alone the course of the world, which permanently puts a pistol to men's heads." Adorno, "Commitment," 180. For more, see the forthcoming cluster on commitment in $V L C$ and my introduction there, written while thinking about Elaine's legacy.

5. Sekers, The Potteries, n.p.

6. Freedgood, Victorian Writing about Risk, xi.

7. Freedgood, Victorian Writing about Risk, 3.

8. Freedgood, Factory Production in Nineteenth-Century England, ix.

9. Freedgood, The Ideas in Things, 2.

10. Freedgood and Schmitt, "Denotatively, Technically, Literally," 3.

11. Freedgood and Schmitt, "Denotatively, Technically, Literally," 4.

12. Sekers, The Potteries, 3.

13. "Luxury Craftsmanship to Ravish the Senses."

14. Church, Josiah Wedgwood, 38.

15. Church, Josiah Wedgwood, 38.

16. On Staffordshire pottery as multispecies assemblage in an imperial frame, I learned much from Kate Thomas's unpublished 2019 lecture, "Bone Body."

17. Engels, Condition, 217.

18. Sedgwick, "Paranoid Reading and Reparative Reading," 144.

19. In a close analysis of one of Elaine's early essays, Mary Mullen has described Elaine's "relentless work to support young scholars." Mary refers to "Freedgood's actions-her support of young scholars, willingness to fight unjust professional norms, and commitment to 
rigorous research while imagining the university and the profession otherwise"; and she cites Elaine's efforts, against often dehumanizing bureaucratic structures, to "enac $[\mathrm{t}]$ forms of social relationality and collective care." Mullen, "Living Dangerously," emphasis added.

20. Elaine Freedgood, personal correspondence with the author, March $6,2018$.

\section{WORKS CiTED}

Adorno, Theodor. "Commitment." In Aesthetics and Politics: The Key Texts of the Classic Debate Within German Marxism, edited by Ronald Taylor, 180. New York: Verso, 2002.

Church, A. H. Josiah Wedgwood: Master Potter. New York: E. P. Dutton, 1908.

Eliot, George. Middlemarch. 1871-72. New York: Oxford University Press, 2008.

Engels, Friedrich. The Condition of the Working Class in England. 1845. London: Penguin, 2005.

Freedgood, Elaine. The Ideas in Things: Fugitive Meaning in the Victorian Novel. Chicago: University of Chicago Press, 2006.

- Victorian Writing about Risk: Imagining a Safe England in a Dangerous World. New York: Cambridge University Press, 2000.

—, ed. Factory Production in Nineteenth-Century England. New York: Oxford University Press, 2002.

—, and Michael Sanders. "Strategic Presentism or Partisan Knowledges." Victorian Studies 59, no. 1 (2016): 117-21.

—, and Cannon Schmitt. "Denotatively, Technically, Literally." Representations 125, no. 1 (2014): 1-14.

Graham, John Meredith, II, and Hensleigh Cecil Wedgwood. Wedgwood. New York: Tudor, 1948.

Kelly, Allison, ed. The Story of Wedgwood. London: Faber and Faber, 1975.

"Luxury Craftsmanship to Ravish the Senses: The Story of Wedgwood," www. wedgwood.co.uk/history\#.

Mullen, Mary. "Living Dangerously: Reflecting on Elaine Freedgood's 'Banishing Panic.” Indiana University Press News Blog, September 12, 2018, https://iupress. typepad.com/blog/2018/09/living-dangerously-reflecting-on-elaine-freedgoodsbanishing-panic-.html.

Sedgwick, Eve Kosofsky. "Paranoid Reading and Reparative Reading, or, You're So Paranoid, You Probably Think This Essay Is about You." In Touching Feeling: Affect, Pedagogy, Performativity, 123-51. Durham: Duke University Press, 2003.

Sekers, David. The Potteries. Princes Risborough, Buckinghamshire: Shire Press, 2000. Thomas, Kate. "Bone Body." Unpublished lecture (shared by email March 27, 2019). Williams, Raymond. Marxism and Literature. Oxford: Oxford University Press, 1977. 